\title{
Aluang Bunian Karawitan Minangkabau dalam Pamenan Anak Nagari dari Penyajian Bagurau ke Presentasi Estetik
}

\author{
Sri Rustiyanti ${ }^{1}$ \\ Fakultas Seni Pertunjukan, Institut Seni Budaya Indonesia (ISBI) Bandung
}

\begin{abstract}
ABSTRAK
Penelitian ini bertujuan untuk memahami peristiwa musik dalam masyarakat Minangkabau dari perspektif budaya. Dalam kajian budaya, semiotika dan estetika tidak dapat dipisahkan. Kekuatan menafsir, memahami, menginterpretasi, dan menganalisis merupakan hal utama dalam penelitian budaya. Berdasarkan penelitian dapat disimpulkan bahwa kesenian tradisi di Minangkabau disebut pamenan anak nagari karena merupakan kesenian tradisi yang tumbuh dan berkembang di tengah kehidupan rakyat dan dimainkan dari rakyat, oleh rakyat, dan untuk rakyat, sedangkan karawitan Minang disebut sebagai aluang bunian karena berbentuk musik (bunyi-bunyian). Peran dan fungsi aluang bunian sebagai hiburan masyarakat Minang dikenal dengan istilah bagurau yaitu acara kesenian yang diadakan semalam suntuk, dimulai dari setelah sholat isya' hingga menjelang subuh. Bagurau adalah bentuk seni pertunjukan tradisi lisan yang merupakan salah satu ciri khas budaya Minangkabau. Dengan perkembangan zaman, ilmu pengetahuan, teknologi, dan konsep estetik aluang bunian (karawitan Minang) tidak hanya sekedar hiburan pamenan anak nagari tetapi mengalami perkembangan dengan mempertimbangkan kaidah-kaidah sebagai presentasi estetik.
\end{abstract}

Kata kunci: aluang bunian, pamenan anak nagari, bagurau, presentasi estetik

\begin{abstract}
The Minangkabau Karawitan of Aluang Bunian in Pamenan Anak Nagari from the Performance of the Aesthetic Presentation Bagurau. Traditional arts in Minangkabau in general are called pamenan anak nagari. The phrase implies the fact that it originated in Minangkabau or Minang folk culture, grew as one of traditional aspects of Minangkabau folk group, and performed by and for the group. Karawitan or traditional musical arts in Minangkabau is called aluang bunian that means musical sounds. An aluang bunian which is presented as an entertainment for Minang people is called bagurau. Bagurau is performed as a cultural event that goes on from dusk (after the evening prayer) till dawn (before the fajr prayer). It is a kind of performing arts - among many other kinds of arts in Minang oral tradition — that exemplifies Minangkabau tradition. Throughout periods of development in science and technology, aluang bunian (Minang karawitan) has underwent an enhancement in its aesthetic values in that it is no longer considered a mere entertainment of pamenan anak nagari but a richer aesthetic presentation with its guiding principles. This article presents cultural, semiotic, and aesthetic studies in which the three contributory aspects (culture, semiotics, and aesthetics) are inseparable since cultural studies involve comprehensions of significations and aesthetic values derived from meaning and sensibility. The abilities in interpreting, inferring, understanding, and analyzing play important role in qualitative research where descriptive analysis method is employed.
\end{abstract}

Keywords: aluang bunian, pamenan anak nagari, bagurau, aesthetic presentation

\section{Pendahuluan}

Kesenian tradisional di Sumatra Barat terdiri dari berbagai jenis. Oleh sebab itu perlu penjelasan berbagai konsep yang biasa dipakai dalam kesenian tradisional di wilayah itu dan berhubungan dengan judul artikel ini. Konsepkonsep itu berupa: karawitan, aluang bunian,

\footnotetext{
Alamat korespondensi: Jurusan Seni Tari, Fakultas Seni Musik, ISBI Bandung. Jln. Buah Batu No.212 Bandung. E-mail: rustiyantisri@yahoo.com. HP: 081221418454
} 
pamenan anak nagari, dan bagurau. Kata karawitan oleh para ahli musik disebutkan berasal dari kata ra yang artinya menghormati, memuja, mendewakan, dan wit artinya para leluhur. Jadi pengertian karawitan yang dimaksud adalah pendewaan atau pemujaan kepada para leluhur yang dibuktikan dengan penggunaan seni suara, seni tari, dan lain sebagainya sebagai media kepentingan ritual. Oleh karena itu ada anggapan dari masyarakat, khususnya yang masih memegang kukuh dengan kepercayaan tertentu, bahwa ada beberapa jenis kesenian yang bersifat sakral. Dalam pengertian umum Seni Karawitan sering diartikan sebagai seni musik tradisi Indonesia yang menggunakan tangga nada pentatonis atau dikenal sebagai laras. Terdapat banyak jenis laras, tetapi yang paling terkenal dalam musik tradisi Indonesia, khususnya Jawa, Sunda, dan Bali, serta telah populer di dunia, adalah laras Pelog dan Slendro. Oleh sebab itu seni karawitan sering disebut sebagai seni suara yang bertangga nada Pelog dan Slendro.

Sejak jaman dahulu orang Minangkabau sudah mempunyai istilah aluang bunian untuk bunyi-bunyian dari alat-alat musik (karawitan) asli Minangkabau. Kata aluang bunian berasal dari kata a yang artinya tidak (bukan) dan luang yang artinya bunyi (udara) yang keluar dari lubang, sedangkan bunian artinya gaib (halus). Aluang bunian adalah nama musik karawitan lagu. Lagu saisuak atau buhun (lama) adalah lagu untuk menghormati roh nenek moyang yang bersifat ritual yang merupakan bagian dari upacara agama (Kamus Besar Bahasa Indonesia, 1995: 488). Di sini aluang bunian bukan berarti bunyi yang dihasilkan oleh hal-hal yang gaib (bunyi gaib), tetapi bunyi yang dihasilkan oleh vokal manusia.

Kesenian Minangkabau kebanyakan merupakan pamenan anak nagari karena merupakan kesenian tradisi yang tumbuh dan berkembang di tengah kehidupan rakyat dan dimainkan dari rakyat, oleh rakyat, dan untuk rakyat. Kesenian ini dipertunjukkan untuk memperingati acara-acara keagamaan maupun sosial kemasyarakatan. Aluang bunian dan bagurau menjadi bagian dari konsep kesenian pamenan anak nagari.

Konsep Bagurau dalam seni pertunjukan masyarakat Minangkabau, tidaklah diketahui secara pasti asal-usulnya. Sampai saat ini belum ditemukan hasil penelitian yang mengkaji riwayat munculnya kata bagurau sebagai istilah pertunjukan, namun istilah ini ditengarai muncul dari tradisi budaya lisan (oral tradition) yang merupakan salah satu ciri khas kebudayaan Minangkabau. Tradisi bercakapcakap atau budaya bercerita dalam suasana yang akrab, sindir-sindiran melalui ungkapan-ungkapan bahasa yang tajam merupakan kebiasaan yang sudah umum dan dikenal luas dalam masyarakat Minangkabau.

\section{Pembahasan}

Aluang bunian yang termasuk dalam kelompok alat bunyi-bunyian (karawitan) merupakan identitas local genius masyarakat Minangkabau yang dikenal dengan istilah pamenan anak nagari (Daryusti, 2010: 26). Istilah ini dari bahasa Minang, yang berarti permainan rakyat dari daerah setempat (baca: Minangkabau). Permainan rakyat Minangkabau sebagai kesenian tradisional, sesuai dengan sistem masyarakatnya yang demokratis dan mendukung falsafah persamaan dan kebersamaan antar manusia, bersifat terbuka, yaitu dari dan untuk masyarakat. Oleh karena sifatnya yang terbuka sebagai milik bersama, maka pamenan anak nagari menjadi mudah berubah akibat persentuhan dengan kebudayaan luar. Pamenan anak nagari sebagai kesenian merupakan salah satu unsur budaya yang dihasilkan oleh masyarakat yaitu orang-orang yang hidup bersama dan memiliki rasa saling ketergantungan. Tegasnya kesenian tidak selalu berdiri sendiri dalam kehidupannya, tetapi merupakan salah satu bentuk aktivitas budaya yang senantiasa terkait dengan kehidupan sosial budaya (Martono, 2011: 4).

Aluang bunian terdiri atas karawitan vokal yang dikenal dengan nama dendang dan karawitan instrumental yang dikenal dengan istilah corek cumandang giri (M. Kadir, 1987: 13). Aluang bunian dalam karawitan vokal (dendang) antara lain:

1. Runguih, melagu pelan-pelan tanpa kata

2. Sinanduang, yaitu melagu pelan-pelan dengan pantun.

3. Kuai, yaitu nyanyian memakai suara tinggi secara 
solo dengan pantun, dimana baris kedua dari pantun di-kuai-kan secara bersama-sama.

4. Dendang, yaitu menyanyikan pantun dengan irama tenang, gembira dan sedih. Dendang termasuk lagu pop di Minangkabau.

5. Ratok, yaitu dendang yang berirama ratap, tangis, dan sedih. Semula ratok merupakan manifestasi jiwa wanita dalam keadaan terdesak yang kemudian berkembang menjadi ratok pitoloang.

Adapun aluang bunian dalam karawitan instrumentalia 'corek cumandang giri', antara lain:

1. Marangu, yaitu bunyi-bunyian yang dihasilkan dari alat-alat tiup seperti:

- Bansi, yaitu alat tiup yang menghasilkan bunyi yang melodius dan gaya lagunya

melankolis, sehingga menimbulkan kesan yang paling enak (indah) di antara alat tiup lainnya.

- Saluang, sejenis alat tiup yang lain. Pada mulanya saluang hanya terdapat dan berkembang di daerah pusat Minangkabau (Tanah Datar, Agam, dan Limapuluh Koto). Saluang selalu mengiringi dendang. Pesaluang dan pedendang dalam sebuah pertunjukan pada umumnya terdiri dari empat orang, yaitu dua orang pria sebagai pesaluang dan dua orang wanita sebagai pedendang. Mereka bersaluang dan berdendang secara bergantian sambung-menyambung tanpa memutus ritme lagu.

- Sarunai, termasuk jenis alat tiup yang menghasilkan bunyi yang paling tinggi dan melengking di antara alat tiup yang lain.

2. Guguah, yaitu bunyi-bunyian pukul yang dihasilkan oleh alat-alat pukul, seperti:

- Talempong, sejenis alat pukul yang dimiliki oleh seluruh pelosok Minangkabau. Dalam memainkan talempong ada dua cara, yang pertama menenteng dua atau tiga buah talempong yang disebut talempong pacik, yang dimainkan oleh empat orang. Cara yang kedua dengan menggunakan standard atau rancakan, yang disebut talempong rea. Talempong rea berisi delapan buah talempong yang dimainkan oleh seseorang dengan menggunakan dua tangan untuk memukulnya.

- Gandang, merupakan alat musik tradisional yang mempunyai dua sisi muka, setiap muka gandang berupa kulit. Ada yang bermuka dua sama besar dan ada pula gandang yang bermuka satu besar dan satu kecil. Gandang Tabut yang berukuran besar menghasilkan suara yang lebih keras dan menggema dibanding gandang keling yang berukuran lebih kecil.

- Canang, seperti talempong, tetapi berukuran lebih besar.

- Adok, sejenis gendang yang mempunyai sisi muka yang berukuran kecil maupun besar.

3. Gesek, untuk memainkan rebab.

4. Garatiek, untuk memainkan kecapi

Selain itu masih terdapat jenis alat-alat karawitan Minangkabau lainnya, seperti sampelong (alat tiup), canang (alat pukul), rabab (alat gesek), tambur (alat pukul), tasa, dan adok (alat pukul).

Bagurau berakar dari kebiasaan masyarakat Minangkabau untuk berkumpul bersama sambil bercerita dan bercanda saling sindirmenyindir, bahkan juga bisa saling mengejek (mencemooh), dalam suasana yang dialogis dan akrab, menyebabkan masyarakat Minangkabau dikenal sebagai masyarakat yang suka dan pintar bicara. Kebiasaan berkumpul ini sekarang banyak ditemukan di tempat-tempat umum, dan yang paling banyak dijadikan tempat berkumpul adalah lapau (kedai kopi). Hampir di seluruh pelosok Sumatra Barat yang mayoritas penduduknya Minangkabau banyak ditemukan kedai kopi yang pada saat-saat tertentu, terutama pada sore dan malam hari, ramai pengunjung. Para pengunjung umumnya adalah kaum laki-laki.

Pengertian yang hampir sama dengan istilah kata bagurau adalah berhandai-handai, yang kemudian juga ikut membentuk tradisi kesenian di Minangkabau, yakni barandai. Kesenian barandai sebagai salah satu bentuk pamenan anak nagari, juga berarti sebagai tradisi bercakap-cakap atau berandai-andai dalam suasana yang akrab dengan menggunakan bahasa malereang (sindiran), kiasan, pantun, dan pepatah-petitih. Dari inilah lahir kesenian barandai, suatu kesenian teater rakyat khas Minangkabau. Barandai merupakan gabungan teater dan tari, karena mengungkapkan sebuah cerita yang diangkat dari kaba Minangkabau dan dipersembahkan dengan tarian. Tempat pertunjukan randai biasanya di ruangan terbuka dalam sebuah gelanggang (arena terbuka) yang 
dikelilingi oleh para penonton. Pendukung randai terdiri atas kelompok pemain musik, pemain gerak gelombang, dan pemain karakter tokoh. Pemain gerak gelombang bergerak dengan gaya pencak silat dan pemain karakter tokoh menampilkan peran sesuai dengan suasana cerita. Randai sebagai seni kolektif dalam penyajiannya mempunyai dua unsur, yaitu unsur pokok dan unsur penunjang. Unsur pokok: gerak gelombang, cerita, dendang, dan pelaku. Unsur penunjang: musik tradisional Minangkabau, tata rias dan busana, tata pentas, tarian (selingan), penonton, setting, dan lighting.

Pertunjukan bagurau saluang dan dendang, dengan syair-syair yang didendangkan terdiri dari pantun, kiasan, dan pepatah-petitih. Dengan demikian, istilah bagurau ataupun barandai dalam tradisi budaya masyarakat Minangkabau merupakan suatu tradisi keseharian atau merupakan suatu konsep sosial yang hidup dalam diri orang Minangkabau. Dari beberapa penjelasan ini, maka kata bagurau dapat diartikan sebagai suatu konsep masyarakat Minangkabau untuk menyebut suatu kegiatan sekelompok orang yang bermain, berkelakar, atau menceritakan sesuatu di antara sesama dalam suasana keakraban. Jadi kata bagurau pada awalnya bukanlah suatu konsep pertunjukan, tetapi merupakan konsep kehidupan keseharian yang ada dalam masyarakat Minangkabau. Sistem kekerabatan matrilinial dengan konsep komunal (kekeluargaan) yang kuat dalam masyarakat Minangkabau mungkin merupakan salah satu faktor pendorong munculnya konsep bagurau sebagai konsep sosial, yang kemudian berkembang menjadi konsep pertunjukan saluang dan dendang.

Estetika adalah ilmu yang mempelajari segala sesuatu yang berkaitan dengan keindahan,

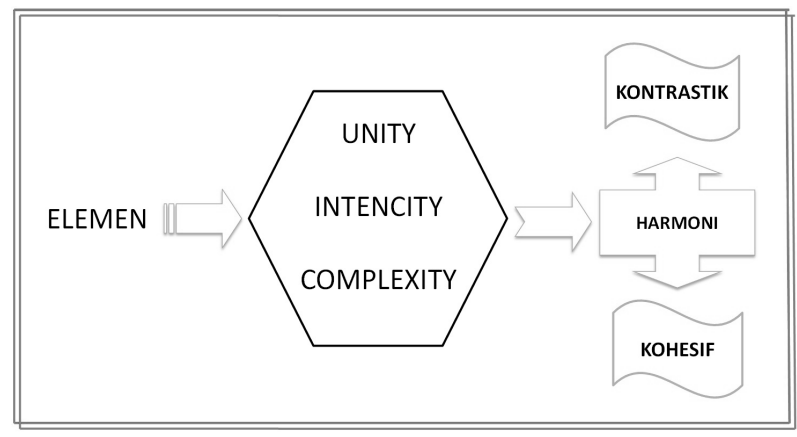

Gambar 1. Elemen estetika terdiri atas: unity, intencity, dan complexity. (Model Monroe Beardsley) mempelajari semua aspek dari apa yang kita sebut keindahan (Djelantik, 2001: 7). Ada tiga hal sifat estetik yang paling mendasar pada suatu karya seni yaitu unity, intensity, dan complexity (Beardsley, 1958: 505-508).

Aluang bunian semula sebagai pamenan anak nagari tidak terlepas dari unsur-unsur spontanitas, kebersamaan antara penonton dan tontonan, ketidakterikatan antara pemain yang satu dengan yang lain, waktu yang panjang, semalam suntuk bahkan bisa berhari-hari, dan kesederhanaan dalam segala aspek. Saat ini, unsur-unsur itu telah mengalami perubahan, sesuai dengan pergeseran konsep estetik yang mengikuti setiap zaman atau kebutuhan. Randai yang semula sebagai pamenan anak nagari kini menjadi sebuah nomor pertunjukan yang telah dikemas sedemikian rupa sehingga menjadi pertunjukan yang lebih menarik, inovatif, dan kreatif. Pada proses pengungkapan ide musikal dalam karya musiknya, Slamet Abdul Sjukur selalu memikirkan segala konsekuensi dari keinginan yang ingin dicapainya. Semua hasil dari proses berjalan menurut kepekaan imajinasi dan kreativitas pemain (Maria, 2013: 109). Seni kemas inilah yang oleh Maquet disebut art of acculturation atau pseudo traditional art, berbeda dengan pertunjukan yang secara kontekstual hanya disajikan untuk masyarakat setempat yaitu art by destination.

Seni kemas wisata memiliki 5 unsur antara lain: 1) imitasi atau tiruaan dari aslinya, 2) dikemas singkat atau padat, 3) meninggalkan nilai-nilai sakral, magis dan simbolisnya, 4) penuh variasi, dan 5) murah (Soedarsono, 1999: 439). Pengemasan yang dilakukan selain pemadatan waktu pertunjukan dari semalam suntuk menjadi

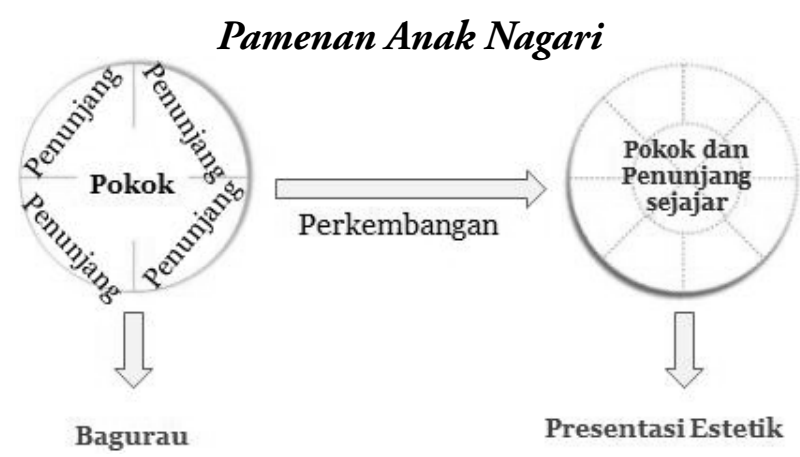

Gambar 2. Transformasi perkembangan pamenan anak nagari dari penyajian bagurau menjadi presentasi estetik 
kira-kira tiga jam, juga penyatupaduan antara unsur pokok (pelaku, cerita, dendang, dan gelombang) dan unsur penunjang (pentas, busana, make up, setting, lighting, tarian, karawitan, dan penonton). Namun perubahan yang terjadi tidak memunculkan konflik karena mereka menyadari perkembangan randai mengikuti dinamika kehidupan masyarakat. $\mathrm{Hal}$ ini menunjukkan bahwa perjalanan kehidupan manusia tidak statis tetapi selalu berubah dalam mengembangkan karya cipta seni untuk mencari idiom-idiom baru.

\section{Fungsi Aluang Bunian dalam Kehidupan Masyarakat Minangkabau}

\section{Fungsi Ritual}

Aluang bunian sebagai karawitan atau musik tradisi adalah suatu jenis musik yang bersifat kontekstual dengan adat tradisi dan sangat lekat dengan kehidupan masyarakatnya. Oleh karena itu musik tradisi sering disebut sebagai musik fungsional, dalam arti suatu jenis musik yang banyak digunakan untuk kepentingankepentingan tertentu yang berhubungan dengan kelangsungan adat istiadat masyarakatnya. Dalam kegiatan-kegiatan upacara yang sifatnya religius, aluang bunian senantiasa hadir sebagai pelengkap sekaligus merupakan kebutuhan yang seolah-olah tidak bisa ditinggalkan. Sebagai contoh upacara adat Tabuik dalam masyarakat Padang Pariaman.

Festival Tabuik merupakan salah satu tradisi tahunan dalam masyarakat Pariaman (Navis, 1986: 264). Festival ini telah berlangsung selama puluhan tahun, bahkan diperkirakan telah ada sejak abad ke-1 masehi. Upacara ritual Tabuik merupakan bagian dari peringatan hari wafatnya cucu Nabi Muhammad SAW, yaitu Hussein bin Ali yang jatuh pada tanggal 10 Muharam, waktu yang sudah terpilih dan ditetapkan seperti halnya dalam pelaksanan upacara ritual Seren Taun, tanggal 22 Bulan Rayagung sebagai bulan terakhir dalam perhitungan kalender Sunda (Budi, 2014: 143). Sejarah mencatat, Hussein beserta keluarganya wafat dalam perang di padang Karbala. Tabuik sendiri diambil dari bahasa Arab 'tabut' yang bermakna peti kayu. Nama tersebut mengacu pada legenda tentang kemunculan makhluk berwujud kuda bersayap dan berkepala manusia yang disebut Buraq. Legenda itu mengisahkan bahwa setelah wafatnya cucu sang Nabi, kotak kayu berisi potongan jenazah Hussein diterbangkan ke langit oleh Buraq. Berdasarkan legenda inilah, setiap tahun masyarakat Pariaman membuat tiruan dari Buraq yang sedang mengusung tabut di punggungnya. Menurut kisah yang diterima masyarakat secara turun temurun, ritual ini diperkirakan muncul di Pariaman sekitar tahun 1826-1828 Masehi. Tabuik pada masa itu masih kental dengan pengaruh dari Timur Tengah yang dibawa oleh masyarakat keturunan India penganut Syiah. Pada tahun 1910, muncul kesepakatan antar nagari untuk menyesuaikan perayaan Tabuik dengan adat istiadat Minangkabau, sehingga berkembang menjadi seperti sekarang.

Upacara penyambutan tamu merupakan kegiatan adat yang sering dijumpai pada suatu daerah untuk menyambut seseorang atau kelompok orang yang memiliki kedudukan dan fungsi penting dalam masyarakat. Dalam kegiatan ini, aluang bunian dipertunjukkan untuk memberikan kesan meriah dan rasa senang masyarakat atas kedatangan tamu. Dalam pertunjukkannya, aluang bunian biasanya tidak hadir secara tunggal, tetapi juga sering diiringi baik secara bersamaan maupun bergantian dengan kesenian lainnya.

Upacara Pengangkatan Penghulu (Batagak Panghulu), untuk menggantikan penghulu yang sudah meninggal atau karena sesuatu alasan tertentu harus diganti, sudah menjadi tradisi di Minangkabau. Penghulu ialah orang yang memegang peranan dan pengaruh besar dalam adat Minangkabau. Sebagai pemimpin dalam kaumnya, seorang penghulu selalu berusaha untuk kepentingan anak-kemenakan yang dipimpinnya maupun masyarakat lainnya (Hakimy, 1994). Seseorang yang telah diangkat menjadi penghulu hendaknya mempunyai prestise sebagai pemimpin dan selalu memperhatikan setiap sikap, tingkah laku dan tindakan yang dapat merusak nama baik kepenghuluannya. Upacara 
batagak panghulu biasanya dilangsungkan di medan nan bapaneh (lapangan terbuka jika hujan kehujanan dan panas kepanasan), di mana perjamuan dilangsungkan selama tiga hari. Hari pertama dinamakan batagak gadang (mendirikan penghulu) dilaksanakan di rumah gadang. Hari kedua, perjamuan dimeriahkan dengan kesenian aluang bunian serta jamuan makan-minum. Hari ketiga, hari pararakan diiringi dengan tari gelombang dan aluang bunian diarak ke rumah bako, pararakan dengan memakai payung kuning. Tradisi ini terus dipertahankan sampai saat ini. Nilai dan fungsi ritual pertunjukan aluang bunian dapat dilihat pada upacara tersebut (Kartomi dalam Davis, 1979: 21).

\section{Fungsi Hiburan}

Karawitan sebagai kalangenan hiburan sama halnya dengan seni tari, bermula dari hiburan untuk mengisi waktu senggang dengan menyanyi. Hal paling penting di sini adalah seni semata-mata hanya difungsikan sekedar untuk kepuasan jiwa, tanpa terikat oleh pakem-pakem tertentu yang dapat mengakibatkan sangsi adat atau sangsi ritual. Masyarakat dapat terlibat langsung atau berempati, sehingga penonton dan tontonan saling berinteraksi, menikmati, serta melakukan kegiatan seni itu sesuai dengan keinginan atau emosi spontan dari setiap individu. Demikian pula halnya ketika berkembang sebagai seni pertunjukan yang fokusnya sebagai hiburan, yang diharapkan dari masyarakat adalah adanya rasa nyaman atau kepuasan hati ketika menikmati tontonan tersebut. Sudah barang tentu kesenian yang melekat dalam bagian kehidupan orang Minang itu juga diwarnai pula oleh pandangan hidup yang sesuai dengan dasar filsafat berbunyi duduak bapamenan tagak baparentang (dalam Undang Undang Nan IX Pucuk), yaitu masyarakat Minang tidak suka berdiam diri melamun tanpa melakukan sesuatu perbuatan apa pun. Oleh karena itu, mereka selalu berusaha dan bekerja untuk mengisi waktu-waktu senggangnya sehingga menghasilkan karya seni dalam berbagai bentuk.

Duduak bapamenan (duduk sambil bermain) menghasilkan seni yang bisa dilakukan dengan duduk, seperti seni musik, seni sastra, dan seni rupa, sedangkan tagak baparentang (berdiri sambil bergerak) menghasilkan seni tari dan pencak silat yang sering dilakukan oleh anak-nagari dalam bentuk pamenan anak nagari. Duduak bapamenan (duduk sambil bermain) disajikan dengan duduk-duduk beristirahat. Meskipun demikian, duduak bapamenan bukan berarti hanya menampilkan seni yang sifatnya sambilan, kegiatan ini juga dapat merespon aktivitas untuk melakukan gerak, misalnya dengan bermain gendang memacu kaki untuk mengikuti irama gendang 'dima-a bunyi gandang kasinan kaki dirantakkan' (di mana bunyi gendang di situ kaki dihentakkan).

Penyajian musik aluang bunian sering dikombinasikan dengan orgen tunggal, yaitu sejenis musik yang sedang marak perkembangannya di Sumatera Barat saat ini. Musik orgen tunggal ini menggunakan keyboard tunggal sebagai alat musiknya, di mana telah tersedia bermacam-macam musik untuk kebutuhan pertunjukan musik secara umum dan bebas. Musik yang disajikan dalam orgen tunggal telah diprogram dengan bahasa pemrograman tersendiri dengan menggunakan alat musik solo keyboard. Musik dalam sajian seperti inilah yang sekarang lebih banyak atau sering ditampilkan untuk berbagai kegiatan atau upacara keadatan yang diselenggarakan masyarakat. Dengan bentuk yang telah termodifikasi, musik aluang bunian dapat menyajikan lebih banyak pilihan lagu dan pilihan aliran musik. Hal ini menyebabkan semakin banyak musik yang menjadi kegemaran masyarakat mampu atau dapat ditampilkan. Bagi orang yang menikmati musik itu timbul dorongan dari dalam dirinya untuk ikut berekspresi atau bereaksi. Di sini dapat dikatakan bahwa orang yang menyaksikan pertunjukan musik itu telah terhibur oleh musik yang disajikan.

Tingkat keterhiburan masyarakat menyaksikan pertunjukan musik aluang bunian memberikan signal bahwa musik tersebut telah berfungsi sebagai media hiburan bagi masyarakat, sesuai fungsi ketiga musik bagi masyarakat (Merriam, 1987). Penampilan musik 
gandang biasanya sering dimanfaatkan untuk acara arak-arakan, yang berfungsi untuk hiburan dan menandakan suka-ria, seperti menyambut kedatangan tamu. Hal ini sesuai dengan sistem kehidupan demokratis masyarakat Minangkabau yang setia dan selalu mendukung falsafah kebersamaan.

Upacara pesta perkawinan merupakan upacara terpenting dalam masyarakat Minangkabau. Prosesi pernikahan bertujuan untuk memberitahukan kepada masyarakat bahwa orang yang menyelenggarakan upacara tersebut telah menikahkan anggota keluarganya dengan orang lain yang telah disetujui atau direstui (Muchtar dan Gusnawirta, 2004). Di samping sebagai media pemberitahuan kepada masyarakat, upacara pesta perkawinan juga merupakan media untuk mengungkapkan rasa syukur penyelenggara upacara, sehingga diharapkan keluarga, kaum kerabat, dan anggota masyarakat sekitarnya dapat merestui mempelai pria dan wanita yang tidak lain ialah anggota keluarga besar mereka. Pada upacara pesta perkawinan ini, musik aluan bunian biasanya hadir untuk memberikan kesan meriah pada upacara tersebut. Selain itu, dengan adanya musik aluan bunian, pihak penyelenggara upacara mengharapkan para tamu yang diundang dapat dituntun menuju ke lokasi upacara.

\section{Fungsi Pertunjukan}

Dalam hal penyajian sebagai pertunjukan, aluang bunian dapat disajikan baik hanya berupa vokal dendang (berirama gembira), ratok (berirama sedih, ratap), ataupun pertunjukan instrumen musik karawitan Minang. Musik talempong kreasi dapat pula dipertunjukkan dalam kegiatan ini, baik pertunjukan tunggal maupun pertunjukan gabungan dengan alat musik aluang bunian yang lain. Musik talempong kreasi dapat bertindak sebagai iringan musik tari-tarian penyambutan tamu seperti tari gelombang. Pertunjukan talempong kreasi pada acara penyambutan tamu dimainkan untuk menciptakan suasana dan nuansa semarak pada upacara tersebut. Di sini, musik talempong kreasi berubah fungsi, dari sekedar menciptakan nuansa meriah dan semarak (hiburan), menjadi musik pengiring untuk pertunjukan tarian.

Secara umum kesenian atau seni pertunjukan berfungsi sebagai media hiburan bagi masyarakat. Demikian pula halnya dengan musik talempong kreasi ini. Talempong kreasi adalah musik tradisional Minangkabau yang telah dimodifikasi baik dari sisi sistem tangga nada, bentuk penyajian, maupun alat-alat musik yang digunakan, walaupun instrumen musik pendukung utamanya tetap instrumen musik tradisi, yaitu: talempong, gandang, canang, bansi, dan saluang.

Saat ini, pertunjukan aluang bunian musik talempong kreasi dapat dinikmati secara bersamaan dengan musik orgen tunggal. Dalam pertunjukannya orgen tunggal menjadi pengiring utama dengan beberapa bunyi alat musik telah diprogram menjadi kesatuan yang utuh, seperti: drum, gitar, piano, gitar bas, dan string. Beberapa alat musik melodis dapat juga disediakan dari musik ini untuk saling bergantian mengisi melodi dengan talempong melodi. Talempong dasar, talempong tinggi, canang dasar, canang tinggi, dan gandang masih menjalankan fungsi dasarnya sebagai pengisi rhythm, pembentuk akord, dan pengatur tempo. Perpaduan kedua musik tersebut menghadirkan dua jenis musik yang berbaur menjadi satu, yaitu musik Barat dan musik tradisi.

Bentuk-bentuk serta jenis seni karawitan sangat beragam, tanpa diketahui penciptanya. Pada kenyataannya, masyarakat dapat memilahmilah baik nama, kelompok, bentuk, maupun laras yang dipergunakan, seperti di Jawa Tengah ada Klenengan, Cokekan, Macapat, dan Uro-Uro. Di Sunda ada Tembang, Kawih, Kliningan, dan Degung, sementara di Bali ada Grantang, Gender, Pategak (permainan lagu intrumental dengan komposisi kuno seperti Sekati, Sekar Gendotan, dan Sekar Sunsang).

Ungkapan emosi lahir secara spontan dari dalam diri manusia. Setiap manusia mempunyai ekspresi emosional yang berbeda-beda tergantung pada interpretasi terhadap sesuatu yang dilihatnya. Ungkapan emosi itu dapat berupa rasa suka, duka, senang atau tidak senang, 
terharu, sedih, saat menyaksikan sajian sebuah seni pertunjukan. Dengan diperdengarkannya musik, maka baik secara langsung atau pun tidak langsung menimbulkan atau membangkitkan emosi penonton. Apabila saat dendang atau ratok yang dibawakan dengan iringan musik bernuansa atau bertema parasaian, kegagalan, kekecewaan dan seterusnya, secara spontan membawa dampak pada masyarakat untuk mengekspresikan emosinya, seperti: meneteskan air mata (sedih) dan terharu, maka dapat dikatakan bahwa sajian musik yang ditampilkan tersebut mempunyai fungsi ekspresi emosional. Hal itu menjelaskan musik fungsi yang pertama dari 10 fungsi musik bagi masyarakat (Merriam, 1987). Aluang bunian memiliki nilai tersendiri yang tidak dijumpai pada bentuk seni lainnya.

\section{Badikie Solawat Dulang/Talam sebagai Pamenan Anak Nagari}

Badikie merupakan acara inti dari perayaan Maulid Nabi. Dikie mempunyai arti yang sama dengan zikir, yaitu mengingat atau mengenang. Dapat juga dijelaskan bahwa dikie/zikir dipakai sebagai doa atau puji-pujian yang ditujukan kepada Allah atau Nabi yang dilaksanakan pada waktu-waktu tertentu (Pusat Pembinaan dan Pengembangan Bahasa, 1976: 250). Dalam konteks perayaan Maulid Nabi, Dikie Maulid dapat dikatakan sebagai kegiatan untuk merekonstruksikan kembali ingatan terhadap peristiwa dan sejarah kelahiran Nabi Muhammad

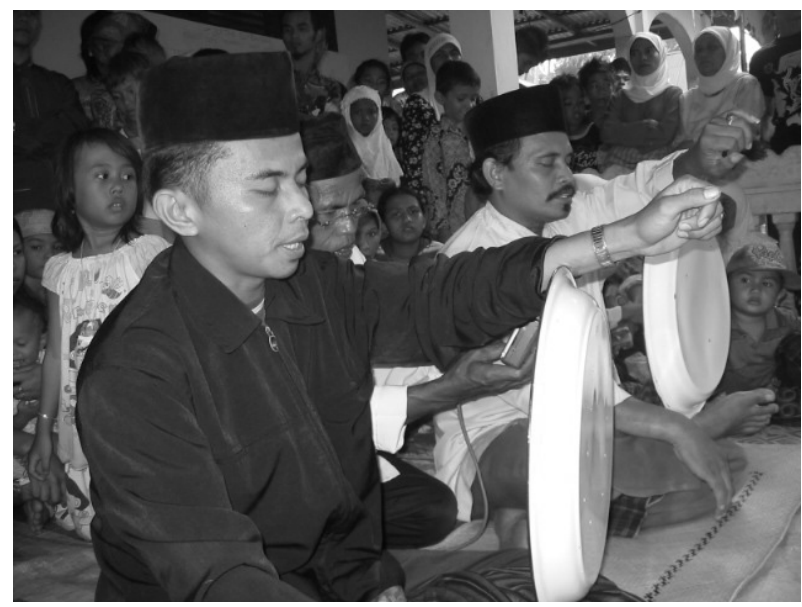

Gambar 3. Bagurau Pamenan Anak Nagari menampilkan solawat dulang/talam
SAW. Kegiatan itu menjadi rutinitas yang diyakini bernilai ibadah, sehingga menjadi ritual religius. Dikie Maulid menjadi sangat penting artinya untuk mengenang dan mengagungkan sosok Nabi Muhammad SAW. Secara tegas juga disebutkan, bahwa kegiatan ini untuk melahirkan kecintaan kepada zat yang hakiki yaitu Nur Muhammad yang meliputi dan memenuhi seluruh rongga tubuh manusia (Tengku Idris, 2008). Dengan demikian dapat dikatakan bahwa upacara Dikie Maulid merupakan ekspresi masyarakat Sungai Sariak terhadap tokoh yang menjadi panutan dalam hidupnya, sekaligus menjadi ritual religius yang penting di samping ritual keagamaan lain pada jamaah Syathariyah Sungai Sariak. Pembacaan syair yang dikemas dalam teks Dikie Maulid dilakukan oleh para Urang Siak (alim ulama) dan berlangsung selama satu malam. Selama kegiatan Dikie Maulid dilaksanakan, pembacaan syairsyair dilakukan secara bergantian oleh dua orang (satu pasang) Urang Siak. Syair yang dilagukan itu sebagian besar terhimpun dalam kitab Syarafal Anam yang secara etimologis berarti manusia yang mulia. Hakekat pelaksanaan perayaan ritual Dikie Maulid, bukan merupakan kegiatan seremonial untuk mengingat Nabi Muhammad belaka, tetapi merupakan kecintaan kepada Dzat Yang Hakiki itu. Dalam pelaksanaannya, banyak para Urang Siak tidak memahami dan mengerti isi dan makna syair-syair dikie yang dilagukannya. Aktivitas pelaksanaan dikie tidak dihayati sesuai dengan teksnya, dan syair itu dibaca sekedar memenuhi tugasnya sebagai petugas pelaksana. Selain itu, para Urang Siak kurang memperhatikan adab yang baik dan kebersihan batiniah. Dalam membacakan seni yang bernafaskan Islam seperti dalam Dikie Maulid, seharusnya Urang Siak harus dapat membacakannya dengan tartil dan tadabbur yang benar (Sukirman, 2008).

Secara sepintas, seluruh syair yang dibacakan selama berlangsungnya kegiatan Dikie Maulid kedengarannya hampir sama. Hal ini dapat didengar dari melodi syair yang dibacakan, maupun dari teks yang dilagukan. Masyarakat secara umum tidak memahami arti dari syair-syair tersebut, mereka hanya mengetahui maksud dari peristiwa Maulid Nabi untuk memperingati hari 
kelahiran Nabi Muhammad. Secara keseluruhan, teks yang dibacakan para Urang Siak (alim ulama) sulit untuk ditangkap makna syairnya secara utuh. Hal itu disebabkan oleh pola irama yang dilagukan berbentuk melodi yang panjang tanpa dapat diberi ketukan atau tempo sehingga terdengar seperti rangkaian sorakan yang panjang dan sangat monoton, serta menyebabkan kejenuhan bagi orang yang tidak memahami maksudnya. Selama berlangsungnya kegiatan dikie, masyarakat yang hadir sibuk menyantap hidangan berupa kue dan minuman yang disajikan. Kaum ibu asyik bercengkrama, dan sebagian tidur lelap sambil menunggu pagi untuk membawa pulang kue yang telah dipajang.

Salawatdulangadalah sastralisan Minangkabau bertemakan Islam. Sesuai dengan namanya, salawat dulang berasal dari dua kata yaitu salawat yang berarti doa untuk Nabi Muhammad SAW, dan dulang atau talam, yaitu piring besar dari loyang atau logam yang biasa digunakan untuk makan bersama. Salawat dulang dipertunjukkan oleh minimal dua klub diiringi tabuhan pada dulang, yaitu nampan kuningan yang bergaris tengah sekitar $65 \mathrm{~cm}$. Dalam bahasa sehari-hari, sastra lisan ini hanya disebut salawat ataupun salawek saja. Di beberapa tempat, salawat dulang disebut juga salawat talam.

Dalam sastra rakyat Minangkabau, salawat dulang adalah penceritaan kehidupan Nabi Muhammad SAW, cerita yang memuji nabi, atau cerita yang berhubungan dengan persoalan agama Islam dengan diiringi irama bunyi ketukan jari pada dulang atau piring logam besar itu (Djamaris, 2002: 150). Pertunjukan salawat dulang biasanya dilakukan dalam rangka memperingati hari-hari besar agama Islam seperti Maulid Nabi, Idul Fitri, dan Idul Adha atau pada upacara bernuansa agama seperti ketika menaiki rumah baru dan khatam al-Quran dan pamenan anak nagari. Pertunjukan ini tidak dilakukan di kedai (lapau) atau lapangan terbuka, tetapi hanya dipertunjukkan di tempat yang dipandang terhormat menurut nilai masyarakat Minangkabau, seperti surau atau masjid, atau tempat untuk tamu yang dihormati bila diadakan di rumah penduduk, yaitu terletak di bagian kiri dari pintu masuk utama, dan dilaksanakan selepas Isya.

Sejarah Salawat dulang berawal dari banyaknya ahli agama Islam Minang yang belajar ke Aceh, di antaranya adalah Syeh Burhanuddin. Ia kemudian kembali ke Minang dan menetap di Pariaman. Dari daerah itu Islam menyebar ke seluruh wilayah Minangkabau. Saat berdakwah, beliau teringat pada kesenian Aceh yang fungsinya menghibur sekaligus menyampaikan dakwah, yaitu tim rebana. Beliau kemudian mengambil talam atau dulang yang biasa digunakan untuk makan dan menabuhnya sambil mendendangkan syair-syair dakwah. Ada juga yang menyatakan bahwa salawat dulang berasal dari tanah datar dan dipergunakan oleh kelompok tarekat syatariah sebagai salah satu cara untuk mendiskusikan pelajaran yang mereka terima.

Dalam pertunjukan salawat dulang, dua pendendang duduk bersisian dan menabuh dulang bersamaan dan saling berhubungan, seperti halnya dalam dunia pertunjukan wayang yang menunjukkan pentingnya hubungan antara karawitan dan dalang. Dalam konteks pertunjukan wayang sosok penabuh instrumen gender dan kendang disebut sebagai bojon dalang atau istri dalang (Sukistono, 2014: 185). Keduanya saling berhubungan dengan berdendang bersamaan atau saling menyambung larik dalam syair. Mereka melakukan tanya jawab, saling serang, dan saling mempertahankan diri sehingga pendendang kadang dijuluki menurut nama-nama senjata, seperti 'peluru kendali' dan 'gas beracun'. Pendendang umumnya laki-laki, namun kini terdapat pula pendendangpendendang perempuan meskipun belum begitu diterima dalam masyarakat Minangkabau sendiri.

Dalam pertunjukan Salawat talam penampilan satu teks yang disebut salabuahan atau satanggak, berdurasi 25-40 menit. Teks salabuahan terdiri atas pambukaan, batang, dan penutup. Bagian batang berisi kaji, yaitu bagian inti salabuahan. Teks tersebut dihafal oleh tukang salawat kata demi kata. Umumnya, teks itu merupakan tafsiran dari ayat-ayat $\mathrm{Al}$-quran atau Hadist. Bagian berikutnya adalah bagian penutup, yang diisi dengan berbalas pertanyaan. Bagian penutup ini juga dapat disisipi dengan pesan-pesan pemerintah, seperti keluarga berencana, supra insus, bahkan pemilihan umum; 
atau sekedar hiburan dengan syair-syair lagu yang tengah populer.

Tradisi Salawat dulang masih berkembang hingga sekarang, hal ini dapat dilihat dari banyaknya tukang salawat, semakin seringnya kesenian ini dipertunjukkan, dan irama pendendangnya semakin terbuka dengan mengikuti perkembangan irama lagu-lagu yang tengah populer di masyarakat. Salawat dulang adalah tradisi Minangkabau yang bersifat terbuka karena memiliki daya adaptif dari segi tema dan irama, kesenian ini dapat diimprovisasikan sesuai dengan hal-hal yang disukai masyarakat baik dari segi isi maupun irama.

\section{Tari Indang sebagai Pertunjukan Presentasi Estetik}

Di Pariaman terdapat kesenian indang yang sampai saat ini eksis sebagai kesenian tradisional bernuansa Islami yang dibina oleh pakar-pakar indang. Awalnya, kesenian indang berfungsi sebagai media komunikasi dalam menyampaikan ajaran Islam, kemudian seni itu berubah sebagai media silaturahmi dalam masyarakat, dan selanjutnya indang berubah sebagai media hiburan pada acara pesta perkawinan, perpisahasan, dan sebagainya (Ali Jastar, 2011). Berkorelasi dengan perubahan fungsinya, tempat pertunjukan kesenian indang yang semula berada di surau pun berubah ke tempat pertunjukan yang dinamakan laga-laga.

Kata indang secara etimologis berarti "nyiru" atau alat penampi beras (Kamus Besar Bahasa Indonesia, 1995: 376). Ada hubungaan asosiatif antara kata indang dengan pertunjukannya, karena dalam pertunjukan ini masing-masing kelompok

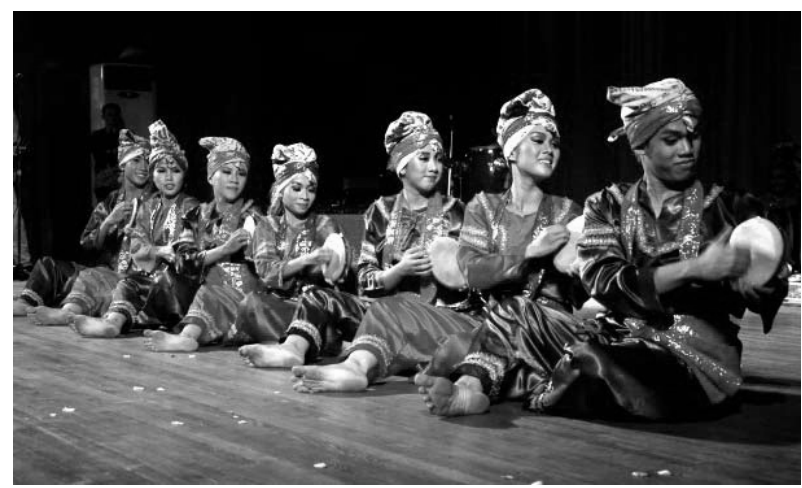

Gambar 4. Pertunjukan Tari Indang sebagai presentasi estetik. me-indang dengan cara menyeleksi kata-kata kiasan lawan sedemikian rupa, sehingga tidak kecolongan. Kata indang juga berhubungan dengan gerakan para pemain yang selalu menggerakkan lengan kiri ataupun lengan kanan ke arah kiri dan ke arah kanan seperti orang me-indang beras yang dilakukan sambil bersila.

Kesenian indang merupakan ragam kesenian khas milik masyarakat pantai atau pesisir Sumatera Barat (Navis, 1986: 264). Menurut Pian, tukang dikie di daerah Sintuak Toboh Gadang (Asril, 1997: 40), munculnya kesenian indang bersamaan dengan perkembangan agama Islam di Minangkabau, khususnya di Pariaman. Berdasarkan hal tersebut, kesenian indang digunakan sebagai sarana pengembangan ajaran agama Islam oleh ulama-ulama dan guru-guru agama di Surau, sehingga masyarakat menganggapnya sebagai kesenian surau. Dalam pertumbuhannya, kesenian indang yang berawal dari lingkungan Surau kemudian dihidupkan oleh kelompok indang dari masing-masing nagari, dan sampai saat ini tiap-tiap nagari di Pariaman memiliki grup kesenian indang. Keberlanjutan kesenian indang berperan membawa misi tertentu, seperti hal-hal yang berkaitan dengan urusan duniawi sebagaimana pertunjukan indang pada tanggal 20 Maret 2009 di Sungai Sariek yang membawa misi partai politik (Yusfil dan Asnimar, 2009: 10).

Secara warisan budaya teks kesenian indang di masyarakat Pariaman dilakukan dengan cara duduk berbaris antar kelompok membentuk segitiga sambil bersila, dan menggunakan properti rebana (rapå). Masing-masing kelompok memiliki personil dengan perannya masing-masing, seperti: tukang dikie, tuo indang, sipatuang sirah, anak

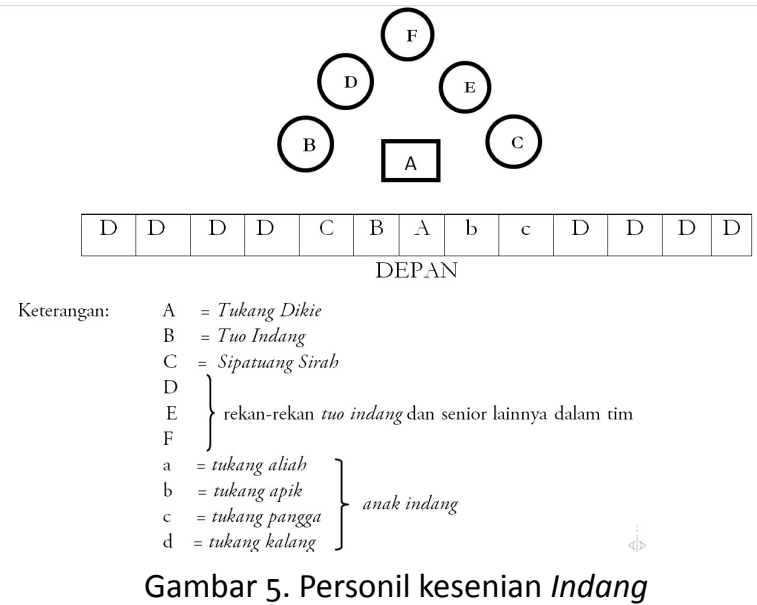


indang, tukang aliah, tukang apik, tukang pangga, kukang kalang.

Pembahasan ini sesuai dengan hasil analisis Margaret Kartomi (2012: 105) tentang peran personil kesenian indang, namun pada personil yang dijabarkan seperti pada gambar 6 terdapat perbedaan yang signifikan pada peran dari personil yang ada di tengah masyarakat Sintuak Toboh Gadang. Contohnya adalah tukang aliah dengan tukang apik, dan tukang bunga salapan yang menggunakan huruf $b$ merupakan personil yang tingkat senioritasnya sama, sementara personil kesenian indang seperti tukang aliah, tukang apik dan tukang bunga salapan yang oleh masyarakat Sintuak dikenal dengan tukang pangga dibedakan tingkat senioritasnya, oleh karena itu hurufnya dibedakan satu sama lain. Di samping itu, tuo Indang dan sipatuang sirah tidak dijabarkan.

Bentuk penyajian tersebut berlanjut terus sampai saat ini, terutama dalam pamenan anak nagari ataupun dalam upacara alek nagari pengangkatan penghulu (Asril, 1997: 40). Secara kontinuitas, penyajian kesenian indang memiliki nilai tersendiri bagi masyarakat yang tidak akan dibiarkan punah, karena membawa ajaran Islam. Teks di atas menunjukkan awal dari penyajian kesenian indang yang dilantunkan oleh tukang dikie, setelah berdendang beberapa bait, disusul kemudian dengan pukulan rapa’i oleh anak indang sambil menggerak-gerakkan badannya ke kiri dan ke kanan dan menciptakan bunyi "prik" dengan cara menggesekkan ibu jari dan jari ke tengah permukaan rapa'i. Setelah bunyi rapa'i berhenti, maka tukang aliah ganti berdendang menyampaikan radaik nya. Baris tertentu dalam bait yang didendangkan tukang aliah diulangi bersama oleh rekan-rekan di kiri kanannya (tukang apik, tukang pangga, dan tukang kalang). Begitu seterusnya selama 60 menit. Waktu 60 menit

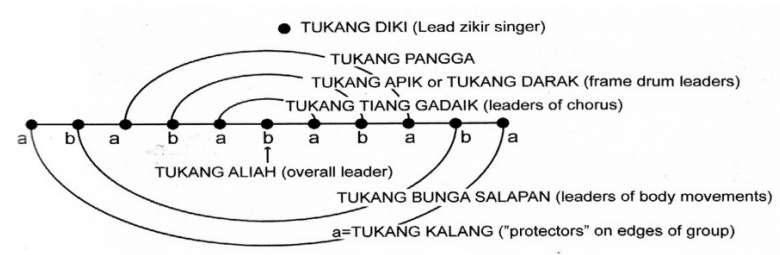

Gambar 6. Personil pesenian Indang (Sumber: Margaret Kartomi, 2012) berikutnya disajikan oleh kelompok kesenian indang lainnya secara bergantian.

\section{Penutup}

Pada saat ini, pandangan orang tentang karya seni selalu mengalami perkembangan dan pergeseran sesuai dengan konsep estetik yang muncul pada setiap zaman. Aluang bunian sebagai pamenan anak nagari tidak hanya sekedar kesenian bagurau atau hiburan semata. Pandangan ini bergeser dan dikoreksi kembali mengingat kecenderungan permainan rakyat dapat menjadi sumber inspirasi dan kreativitas dalam karya-karya seni pertunjukan estetik. Perkembangan konsep, ideologi, sains, dan teknologi, tidak terhindarkan dari kehidupan kultural masyarakat Minangkabau, apalagi hampir sebagian besar masyarakatnya merantau yang pada tingkat tertentu dapat mengubah gaya hidup seseorang.

Globalisasi memang tidak terelakkan pengaruhnya, tetapi pasti ada kekuatan lain sebagai proses seleksi, pemilihan, penyaringan, adopsi, penolakan, pertukaran dan pengaruh inter-kultural yang kompleks. Dari sini diharapkan dapat tercipta sebuah hubungan yang saling menguntungkan (simbiosis mutualistis) dengan budaya tertentu yang positif, konstruktif, dan produktif bagi perkembangan budaya lokal. Begitu pula dengan perkembangan pamenan anak nagari yang bernuansa bagurau digarap kembali menjadi pertunjukan estetik.

Aluang bunian dalam pamenan anak nagari yang dibentuk menjadi suatu kebudayaan baru jelas belum memiliki sendi-sendi yang kokoh. Dalam persaingan kebudayaan, sendi yang kuat bertahan, sedangkan yang goyah ditinggalkan.

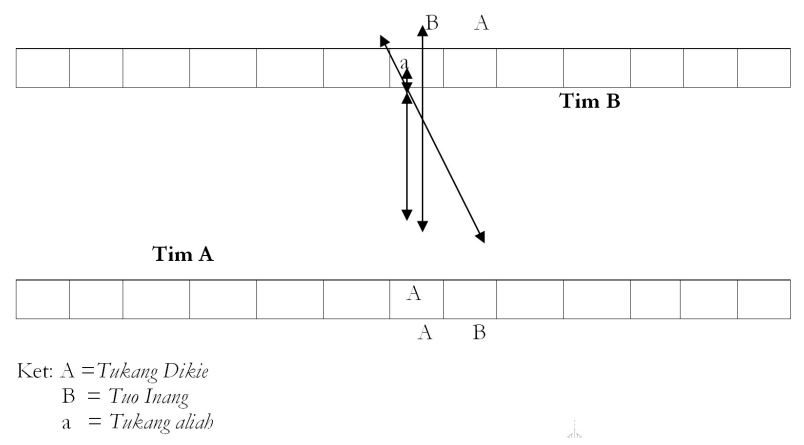

Gambar 7. Posisi personil inti kesenian Indang 
Proses globalisasi bukanlah proses penyeragaman budaya, suku-suku yang mengglobal tersebut akan tetap memelihara identitasnya. Dengan demikian pada proses global-tribes tersebut faktor identitas amat berperan. Hanya suku atau masyarakat yang memiliki identitas yang kuat dan lentur yang mampu bertahan dan menjadi subjek di dalam proses perubahan (proses globalisasi) itu.

\section{Kepustakaan}

Beardsley, Monroe C. 1958. Aesthetics Problems in the Philosophy of Criticism. Harcourt: Brace and Company.

Budi, Dinda Satya Upaja, dkk. 2014. "Angklung Dogdog Lojor pada Upacara Seren Taun” dalam Resital Jurnal Seni Pertunjukan, Vol 15 No 2 Desember 2014.

Desmawardi. 2005. "Maulid Nabi Tradisi Ritual Keagamaan dan Seni di Pariaman Sumatera Barat.” [Laporan Penelitian]. Padang Panjang: STSI.

Departemen Pendidikan dan Kebudayaan. 1995. Kamus Besar Bahasa Indonesia. Jakarta: Balai Pustaka.

Djamaris, Edward. 2002. Pengantar Sastra Rakyat Minangkabau. Jakarta: Yayasan Obor Indonesia.

Daryusti. 2010. Lingkaran Lokal Genius \& Pemikiran Seni Budaya. Yogyakarta: Multi Grafindo.

Dewi, Maria Octavia Rosiana. 2013. "Konsep Minimax Slamet Abdul Sjukur dalam Musik Uwek- Uwek" dalam Resital Jurnal Seni Pertunjukan, Vol. 14 No 2 Desember 2013.

Djelantik, AAM. 1999. Estetika: Sebuah Pengantar. Jakarta: MSPI.

Ediwar. 1999. "Perjalanan Kesenian Indang dari Surau ke Seni Pertunjukan Rakyat Minangkabau di Padang Pariaman Sumatera Barat" [Tesis]. Yogyakarta: Program Pascasarjana Universitas Gadjah Mada.

Gouzali, Saydam. 2004. Kamus Lengkap Bahasa Minang. Padang: Pusat Pengkajian Islam dan Minangkabau (PPIM), Sumatera Barat.

Hadi, Y. Sumandiyo. 2006. Seni dalam Ritual Agama. Yogyakarta: Buku Pustaka.
Hakimy, Idrus., Dt. Rajo Penghulu. 1994. Pokokpokok Pengetahuan Adat Alam Minangkabau. Bandung: Remadja Rosdakarya.

Kadir, M. 1987. Musik Karawitan Minangkabau. ASKI: Padang Panjang.

Kartomi, Margaret J. 1979. "Minangkabau Musical Culture: The Contemporary Scene and Recent Attemps at Its Modernization", dalam Glovia Davis (ed). What is Modern Indonesia Culture?. Ohio: Ohio University Press. 2012. Musical Journeys in Sumatera. Chicago: University of Illionis Press.

LKAAM. 1981. Pelajaran adat minangkabau: Sejarah dan Budaya Padang. Padang: Tropic Offset Printing.

Martono, Nanang. 2011. Sosiologi Perubahan Sosial. Perspektif Klasik, Modern, Posmodern, dan Post Kolonial. Jakarta: PT Radja Grafindo.

Merriam, Allan P. 1987. The Anthropology of Music. Chicago: North Western University Press.

Muchtar, Muchsis, Dt. Bandaro Putiah dan Gusnawirta. 2004. Pelaksanaan Upacara Perkawinan menurut Adat Nagari di Minangkabau. Jakarta: Yayasan Citra Pendidikan Indonesia.

Mukhtar, Asril. 2005. ”Tradisi Maulid Pariaman”. dalam Majalah Gong, No. 69/II. 1997. "Seni Pertunjukan Indang Pariaman Minangkabau, Pergeseran dari Religius ke Profan" dalam Jurnal Seni dan Budaya, No 1. Tahun 1. ASKI Padangpanjang. Navis, A.A. 1986. Alam Takambang Jadi Guru. Jakarta: PT Grafiti Pers.

Soedarsono, RM. 1999. Pertunjukan Indonesia di Era Globalisasi. Yogyakarta: Gajah Mada Press.

Sukistono, Dewanto. 2014. "Pengaruh Karawitan terhadap Totalitas Ekspresi Wayang dalam Pertunjukan Wayang Golek Menak Yogyakarta" dalam Resital Jurnal Seni Pertunjukan, Vol. 15 No 2 Desember 2014.

Yunus, Mahmud. 1971. Sejarah Islam di Minangkabau Sumatera Barat.

Yusfil \& Asnimar. 2009. "Tari Indang Pariaman” [Laporan Magang]. Padangpanjang: Jurusan Tari STSI Padangpanjang. 